Journal of Engineering and Applied Sciences 14 (Special Issue 9): 10642-10649, 2019

ISSN: 1816-949X

(C) Medwell Journals, 2019

\title{
Evaluation Water Pollution of Al-Diwaniyah River in Relation to its Physical and Chemical Properties
}

\author{
${ }^{1}$ Sami Kadhim Hassan, ${ }^{2}$ Ashwaq Saleh Hussein and ${ }^{3}$ Muklis Hakim Muwjid \\ ${ }^{1}$ College of Biotechnology, \\ ${ }^{2}$ College of Education, University of Al-Qadisiyah, Qadisiyah, Iraq \\ ${ }^{3}$ Department of Environment Directorate, Qadisiyah, Al-Diwaniyah, Iraq
}

\begin{abstract}
Five location were selected from Al-Diwaniyah river to study the impact of the city wastes such as rubbers and textile factories output on the physico-chemical properties of the river through the passage in the city during November in the year 2013 and 2014, two locations (in the South and North of Al-Diwaniyah city) were studied in the months of year 2014. Temperature of water, $\mathrm{pH}$, dissolved oxygen, total dissolve solids (salinity), turbidity, electrical conductivity, total alkalinity, total hardness, calcium, magnesium, chloride, sulphates, nitrate and total phosphates. The heavy elements that have environmental danger like $(\mathrm{Fe}, \mathrm{Pb}, \mathrm{Cu}$, $\mathrm{Zn})$ are considered also. The study presents that the temperature of water is between $10-34^{\circ} \mathrm{C}$ and $\mathrm{pH}=$ 7.6. The water of the river is characterized by high aerated $\left(10 \mathrm{mg} \mathrm{L}^{-1}\right)$ as the standard world measures. High values were recorded for dissolve solids, turbidity, electrical conductivity and calcium in some months of these years in the north of Al-Diwaniyah. This due to agricultural usages and animal breeding (Boffalo which swim in the river). On the contrary the values of total alkalinity, total hardness, magnesium, chloride, sulphates, nitrate and total phosphates in the South of the city because of the influence of the polluting elements in the river water. In the North to the general average for the values of these variants are records as: 29 NTU), $1220 \mu$ mhos cm ${ }^{-1}\left(852,127,115,539,72,158,432,0.32,0.03 \mathrm{mg} \mathrm{L}^{-1}\right)$, respectively. In comparison with the South of the city 27 (NTU), $1185 \mu$ mhos $\mathrm{cm}^{-1}$, (854, 121, 113, 598, 85, 169, 440, 0.40, $0.05 \mathrm{mg} \mathrm{L}^{-1}$ ), respectively. While the general values for the heavy metals were rare for $(\mathrm{Pb}, \mathrm{Cu}, \mathrm{Zn})$ in which $\left(0.03 \mathrm{mg} \mathrm{L}^{-1}\right)$ for Fe. There is no serious effects for rubbers and textile factories on most of the above variants for the decreased production of these factories in the time of the study while the difference of the months study recorded serious effects on some of these variants, the pollution in the South of the city decreased in spite of this most of the general values are identical with the world quality of environment and the local water of the rivers because a lot of water is in the river in 2014.
\end{abstract}

Key words: Al-Diwaniyah river, physical and chemical properties, dissolved oxygen, factories, sulphates, standard, quality of environment

\section{INTRODUCTION}

Improving the productivity and development of natural resources is one of the means by which its followers have to find a balance between the increase in population and knowledge of these resources. Thus, the modernization of the manufacturing and production processes of various types is done using advanced technology based on the results of applied scientific research and methods of development and with this technical development. The emergence of new pollution images of the human element resulting from the use of new materials have not been used before and in the midst of this development began some environmental problems facing communities in various parts of the world and these problems fall under the pollution of various types organic and inorganic, there is a chemical and oil and thermal radiation and other pollution which all in the framework of industrial pollutants human environment (Saleh et al., 1980).
That the dumping of industrial and household waste in the waters of the flats and rivers causes great damage to the water environment, the most basic of which is the loss of the aesthetic character of the rivers and lakes in which they are thrown in addition to the serious economic losses resulting from the lack of fish wealth. As well as health damage (Saleh et al., 1980) and in the light of the serious risks that such pollutants may cause, many international studies (Buhrmann et al., 1999), Dart and Stretton (1980), Walker and Weatherley (1999) and local (Maulood et al., 1994; Sabri et al., 1989; Al-Lami et al., 1998, 2001; Abed Ali et al., 2000 and Al-Mashkoor, 2002, 2006) from physical aspects chemical and biological or some of them to identify the quantity and quality of water pollutants.

The city of Al-Diwaniyah depends on the Al-Diwaniyah river as a main source for the processing of raw water used for agricultural purposes directly or for drinking purposes after it is filtered and sterilized in the 
liquefaction stations. This river is an extension of the Euphrates river in Al-Hilla before entering the city of Al-Hilla. As a result of the passage of the river in several cities and human settlements, industrial and agricultural waste containing organic and inorganic substances and the quality of its water quality. Due to the lack of periodic studies of the water of this river, this study aimed to know and evaluate the extent of pollution of the Al-Diwaniyah river in terms of physical properties and chemical and biochemical before entering the city and determine the extent of pollution caused by the waste from the city of Al-Diwaniyah and textile and rubber factories which was received in the river without treatment while passing through the city which is heading south to the area of Sudair and the Eastern district of Al-Hamzah, ending in the territory of Al-Rumaitha district in Al-Muthanna province.

\section{MATERIALS AND METHODS}

Method of collecting samples: Samples from five different sites along the river were collected at a rate of replicates per sample in clean plastic bottles of $1 \mathrm{~L}$ and from the upper surface layer $(30 \mathrm{~cm})$ of the river. The sample of the first site was taken from the North of the city, South of the city from the Khayri area (3 km South of the textile factory). The samples of these five sites were collected. In November of 2013 and repeated the same month in 2014 and sampled samples the second and third sections were collected monthly starting from January to December, 2014 (Fig. 1).
Examination of environmental variables: The samples were collected according to specifications and adopted the common standard analytical methods for estimating and measuring physical and chemical variables according to the American Public Health Association (APHA, AWWA, WPCF, 1985). The variables included.

Physical tests: The temperature was measured by the mercury thermometer at the sampling sites and the visual comparison method was used in the measurement of color and the taste and smell were used in determining the taste and odor of the water. Turbidity was measured in NTU using the Turbidimeter model 2100 A (Total Dissolved Solids (TDS)) by filtration and drying of leachate. The Electrical Conductivity (EC) is measured using the electrical conductivity meter model $31 \mathrm{~A}$ and the micromhus $\mathrm{cm}$ at $25^{\circ} \mathrm{C}$.

Chemical tests: The $\mathrm{pH}$ of the samples was measured on arrival at the laboratory using a $\mathrm{pH}$ meter 62 and the total alkalinity $\left(\mathrm{CaCO}_{3}\right)$ was measured in $\mathrm{mg} / \mathrm{L}$. Total hardness Salts (THS) (mg/L) was corrected with silver nitrate and sulphate (mg/L) was estimated according to the method reported by the World Health Organization (WHO., 1980) by the technique of burning the weight loss in barium sulphate and the Nitrate $\left(\mathrm{NO}_{3}\right)$ was estimated by the method of endol. Total phosphate $\left(\mathrm{mg} \mathrm{L}^{-1}\right)$ was measured spectrally by Spectrophotometer type Shimadzu 160 using the tinid chloride method mentioned in the report of the (Anonymous, 1960) after digestion with sulfuric acid and nitric acid. The trace metals (lead, iron, copper and zinc) were estimated using the atomic absorption

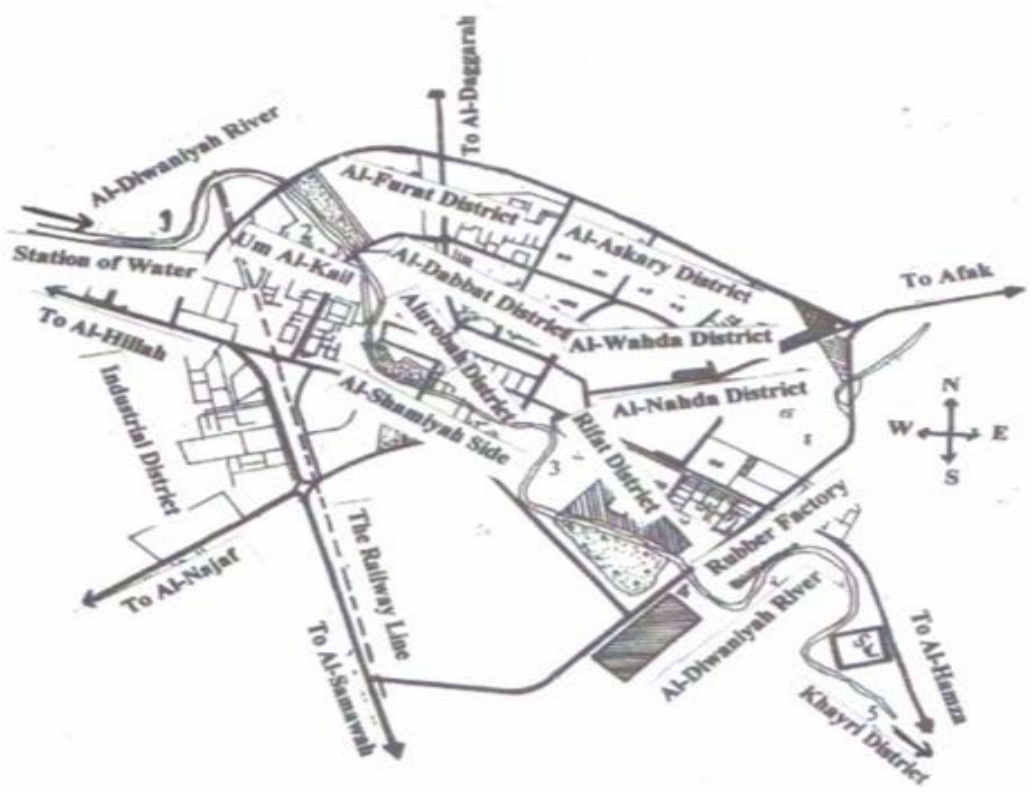

Fig. 1: Al-Diwaniyah city map showing the river and sampling sites 
absorber Atomic Bulk Spectrophotometer Bulk Model-Scientific 210 UGP processed from Bay Unicam Company.

Biochemical tests: Dissolved Oxygen (DO) was estimated using the method reported by the American Public Health Association (APHA, AWWA, WPCF, 1985).

\section{RESULTS AND DISCUSSION}

It was noticed through personal observation that the water of the Al-Diwaniyah river North of the city (the first location) was characterized by taste and smell but it contained small amounts of humus and some floating fat because of the pollution of some cities of Babil province on the water of the Al-Hilla river, the water pollution of the river South of the city of Al-Diwaniyah (the fifth site) increased to the effect of the remnants of the city of Al-Diwaniyah. The results of the study showed that the water temperature values of the five sites studied during the month of November 2013 and 2014 ranged between $20-22^{\circ} \mathrm{C}$. Table 1 which changed according to the seasons of the year, reached between $10-11^{\circ} \mathrm{C}$ ) during January for the year 2014. Table 2 which increased during the spring and reached a maximum during the summer months ranged between $\left(33-34^{\circ} \mathrm{C}\right)$ in August, noting that these temperatures are recorded at the time of measurement and do not cross for changes throughout the day as the water temperature is affected by the ambient air temperature (Al-Nimma, 1982; Al-Mashkoor, 2006). This is recommended by the US Environmental Protection Agency (EPA.,1971) free degree Maximum water level of $32^{\circ} \mathrm{C}$ with a maximum of $3^{\circ} \mathrm{C}$ above normal temperature in watercourses. Any increase due to human activities also affects aquatic life and thus the taste and smell of water, dissolved oxygen values and $\mathrm{pH}$ (Brock, 1967).

$\mathrm{pH}$ values in river water ranged from 7.0-8.3 (rate 7.6) within months of years and were within the allowable standards set by the European Union (EC, WEDC, 1987) 34 and the World Health Organization (WHO., 1980) between (5.5-9.5), the American Public Health Association (APHA, AWWA, WPCF, 1985), the US Environmental Protection Agency (Abbawi and Muhammad,1990), Iraqi Standards (IRPR,1981) and Iraqi Environmental Legislation, 1988) (6.5-8.5) in drinking water and domestic uses. It also falls within the limits mentioned by Peavy et al. in the American public water between (5.3-8.6) and an ideal rate of 6, there were no clear indications of the impact of Al-Diwaniyah contaminants on the $\mathrm{pH}$ values of the river water during the various months of the year as opposed to the total alkalinity values which increased significantly at site 3 South of the city (Table 1 and 2). As household wastes leaking out of the river water increase the number of microorganisms that cause the increased concentration of $\mathrm{CO}_{2}$ in the water and thus increase the concentration of bicarbonates and carbonates that lead to an increase in basal value (Abu Giedria, 1988; WHO., 1994). The wastes of the Rubber and Textile factories loaded with bicarbonate and hydroxyl have the effect of raising basal values on site 5 on the river (Table 1) and this is consistent with what and reached (Eisen and Anderson, 1988).

The narrow range of $\mathrm{pH}$ values at study sites is due to the high regulation capacity in hardness and alkalinity water which rich in bicarbonate (Hynes, 1972). The relatively high $\mathrm{pH}$ values may be due to the high presence of salts of hardness (The American Water Works Association, 1971) which exceeds total alkalinity values due to the contribution of other ions other than calcium and magnesium in the formation of non-carbonic hardness (Tables 1 and 2) is confirmed by Lind (1979). The light values of the Al-Diwaniyah river are in line with Blum (1976) report that most of the rivers in temperate regions tend to lightalkalinity. The present study also agreed with previous studies on the light alkalinity water in Iraq due to the abundance of bicarbonate and carbonate ions.

\begin{tabular}{|c|c|c|c|c|c|c|c|c|c|c|c|c|c|c|c|}
\hline \multirow{2}{*}{$\begin{array}{l}\text { Years location } \\
\text { Variables }\end{array}$} & \multicolumn{7}{|l|}{2013} & \multicolumn{8}{|c|}{2014} \\
\hline & 1 & 2 & 3 & 4 & 5 & Range & Average & 1 & 2 & 3 & 4 & 5 & Range & Average & General average \\
\hline Temp. & 22 & 21 & 20 & 20 & 21 & $22-20$ & 21 & 21 & 20 & 21 & 22 & 21 & $22-20$ & 21 & 21 \\
\hline $\mathrm{pH}$ & 7.6 & 7.7 & 7.7 & 7.7 & 7.6 & 7.7-7.6 & 7.7 & 7.8 & 8.3 & 8.1 & 7.1 & 7 & $8.3-7.0$ & 7.6 & 7.7 \\
\hline Dissolved oxygen & 11.5 & 10.8 & 10.9 & 11.5 & 10.7 & $11.5-10.7$ & 11.1 & 11.1 & 10 & 11 & 9.8 & 10.3 & $11.1-9.8$ & 10.4 & 10.7 \\
\hline Total disso. Solid & 967 & 991 & 983 & 850 & 943 & $991-850$ & 947 & 477 & 483 & 476 & 474 & 470 & $470-483$ & 476 & 712 \\
\hline Turbidity & 10 & 37 & 17 & 9 & 10 & $37-9$ & 17 & 22 & 24 & 22 & 26 & 21 & $26-21$ & 23 & 20 \\
\hline Elecitr. conductiv. & 1229 & 1278 & 1211 & 1196 & 1182 & $1182-1278$ & 1219 & 950 & 965 & 949 & 949 & 937 & $937-965$ & 950 & 1085 \\
\hline Salinity & 786 & 818 & 775 & 765 & 756 & $756-818$ & 780 & 608 & 618 & 607 & 607 & 599 & $599-618$ & 608 & 694 \\
\hline Total alkalinity & 83 & 88 & 105 & 107 & 100 & 83-107 & 97 & 78 & 76 & 80 & 88 & 92 & 76-92 & 83 & 90 \\
\hline Total hardness & 621 & 680 & 700 & 710 & 750 & $621-750$ & 692 & 760 & 780 & 902 & 1010 & 1052 & $760-1052$ & 901 & 797 \\
\hline Calcium & 136 & 160 & 144 & 152 & 224 & $136-224$ & 163 & 111 & 133 & 126 & 128 & 138 & $111-138$ & 127 & 145 \\
\hline Magnesium & 68 & 68 & 83 & 41 & 34 & $34-83$ & 59 & 11 & 79 & 128 & 168 & 183 & $11-183$ & 114 & 87 \\
\hline Chloride & 298 & 238 & 293 & 223 & 253 & $223-293$ & 261 & 151 & 131 & 152 & 160 & 150 & $131-160$ & 149 & 205 \\
\hline Sulphates & 410 & 415 & 430 & 410 & 440 & $360-440$ & 421 & 420 & 445 & 461 & 510 & 545 & $420-545$ & 476 & 449 \\
\hline Nitrate & 0.2 & 0.4 & 0.6 & 0.7 & 0.6 & $0.2-0.7$ & 0.5 & 0.3 & 0.5 & 0.6 & 0.6 & 0.8 & $0.3-0.8$ & 0.56 & 0.53 \\
\hline Total phosphate & 0.02 & 0.03 & 0.04 & 0.04 & 0.05 & $0.02-0.05$ & 0.04 & 0.01 & 0.03 & 0.04 & 0.04 & 0.04 & $0.01-0.04$ & 0.03 & 0.04 \\
\hline $\mathrm{Fe}$ & 0.01 & 0.03 & 0.03 & 0.02 & 0.03 & $0.01-0.03$ & 0.02 & 0.02 & 0.03 & 0.03 & 0.04 & 0.04 & $0.0-0.024$ & 0.03 & 0.03 \\
\hline $\mathrm{Pb}$ & Nill & & & & & & & & & & & & & & \\
\hline \multicolumn{16}{|l|}{$\mathrm{Cu}$} \\
\hline $\mathrm{Zn}$ & & & & & & & & & & & & & & & \\
\hline
\end{tabular}




\begin{tabular}{|c|c|c|c|c|c|c|c|c|c|c|c|c|c|c|c|c|c|c|c|c|c|c|c|c|c|c|c|c|c|}
\hline \multirow{2}{*}{$\begin{array}{l}\text { Month and } \\
\text { location } \\
\text { Variables }\end{array}$} & \multicolumn{2}{|l|}{ Jan } & \multicolumn{2}{|l|}{$\mathrm{Feb}$} & \multicolumn{2}{|l|}{ Mar } & \multicolumn{2}{|l|}{ Apr } & \multicolumn{2}{|l|}{ May } & \multicolumn{2}{|l|}{ Jun } & \multicolumn{2}{|l|}{ Jul } & \multicolumn{2}{|l|}{ Aug } & \multicolumn{2}{|l|}{ Sep } & \multicolumn{2}{|l|}{ Oct } & \multicolumn{2}{|l|}{ Nov } & \multicolumn{2}{|l|}{ Dec } & \multicolumn{2}{|c|}{ North city (2) } & \multicolumn{2}{|c|}{ South city (3) } & \multirow{2}{*}{$\begin{array}{l}\text { General } \\
\text { average }\end{array}$} \\
\hline & 2 & 3 & 2 & 3 & 2 & 3 & 2 & 3 & 2 & 3 & 2 & 3 & 2 & 3 & 2 & 3 & 2 & 3 & 2 & 3 & 2 & 3 & 2 & 3 & Range & Average & Range & Average & \\
\hline $\begin{array}{l}\text { Temp. } \\
\mathrm{pH}\end{array}$ & $\begin{array}{l}10 \\
7.6\end{array}$ & $\begin{array}{l}11 \\
7.6\end{array}$ & $\begin{array}{l}14 \\
7.8\end{array}$ & $\begin{array}{l}15 \\
7.6\end{array}$ & $\begin{array}{l}16 \\
7.6\end{array}$ & $\begin{array}{l}17 \\
7.4\end{array}$ & $\begin{array}{l}19 \\
7.5\end{array}$ & $\begin{array}{l}18 \\
7.5\end{array}$ & $\begin{array}{l}19 \\
7.4\end{array}$ & $\begin{array}{l}20 \\
7.4\end{array}$ & $\begin{array}{l}27 \\
7.8\end{array}$ & $\begin{array}{l}26 \\
7.4\end{array}$ & $\begin{array}{l}33 \\
7.5\end{array}$ & $\begin{array}{l}32 \\
7.4\end{array}$ & $\begin{array}{l}33 \\
7.4\end{array}$ & $\begin{array}{l}34 \\
78\end{array}$ & $\begin{array}{l}30 \\
7.9\end{array}$ & $\begin{array}{l}31 \\
7.7\end{array}$ & $\begin{array}{l}24 \\
7\end{array}$ & $\begin{array}{l}25 \\
7.4\end{array}$ & $\begin{array}{l}20 \\
8.3\end{array}$ & $\begin{array}{l}21 \\
8.1\end{array}$ & $\begin{array}{l}13 \\
7.6\end{array}$ & $\begin{array}{l}14 \\
7.4\end{array}$ & $\begin{array}{l}\text { Oct-33 } \\
7.0-8.3\end{array}$ & $\begin{array}{l}21.5 \\
7.6\end{array}$ & $\begin{array}{l}\text { Nov-34 } \\
7.0-8.1\end{array}$ & $\begin{array}{l}22 \\
7.5\end{array}$ & $\begin{array}{l}21.8 \\
7.6\end{array}$ \\
\hline $\begin{array}{l}\text { Dissolved. } \\
\text { Oxygen }\end{array}$ & 12 & 11.2 & 11.4 & 10 & 12.1 & 11.2 & 10 & 9 & 11.4 & 10.2 & 9.3 & 10.2 & 10.1 & 9 & 9.1 & 8.2 & 9.3 & 9 & 10.2 & 9.1 & 10 & 11 & 10.5 & 9.5 & $9.1-12.1$ & 10.5 & $8.2-11.2$ & 9.8 & 10 \\
\hline $\begin{array}{l}\text { Total } \\
\text { Disso.Solid }\end{array}$ & 917 & 893 & 920 & 905 & 979 & 966 & 881 & 869 & 837 & 826 & 1057 & 1122 & 941 & 999 & 1033 & 1030 & 1035 & 1109 & 515 & 491 & 483 & 476 & 620 & 560 & 483-1057 & 852 & $476-1122$ & 854 & 853 \\
\hline Turbidity & 11 & 10 & 14 & 15 & 22 & 23 & 22 & 20 & 25 & 24 & 43 & 37 & 38 & 35 & 55 & 53 & 46 & 34 & 29 & 35 & 24 & 22 & 13 & 16 & Nov-55 & 29 & Oct-53 & 27 & 28 \\
\hline $\begin{array}{l}\text { Elecit. } \\
\text { Conductivity }\end{array}$ & 12 & 1229 & 1128 & 81109 & 1460 & 1485 & 1314 & 41337 & 1248 & 1270 & 1175 & 1157 & 1046 & 1030 & 1454 & 1331 & 1403 & 1227 & 1024 & 973 & 965 & 949 & 1243 & 1124 & $965-1460$ & 1220 & 949-1485 & 1185 & 12.3 \\
\hline Salinity & 756 & 786 & 722 & 709 & 934 & 950 & 841 & 855 & 798 & 812 & 752 & 740 & 669 & 659 & 930 & 851 & 898 & 785 & 655 & 622 & 618 & 607 & 796 & 719 & 618-934 & 781 & 622-952 & 758 & 770 \\
\hline $\begin{array}{l}\text { Total } \\
\text { Alkalanity }\end{array}$ & 90 & 98 & 88 & 94 & 130 & 100 & 124 & 95 & 117 & 96 & 109 & 125 & 97 & 111 & 170 & 152 & 125 & 131 & 170 & 150 & 76 & 80 & 80 & 127 & $76-170$ & 115 & 80-152 & 113 & 114 \\
\hline $\begin{array}{l}\text { Total } \\
\text { Hardness }\end{array}$ & 500 & 680 & 630 & 750 & 660 & 730 & 627 & 694 & 596 & 659 & 481 & 511 & 428 & 455 & 473 & 462 & 483 & 502 & 420 & 380 & 780 & 902 & 374 & 449 & $374-780$ & 539 & 380-902 & 598 & 569 \\
\hline Calcium & 140 & 224 & 116 & 112 & 205 & 176 & 195 & 167 & 192 & 162 & 90 & 93 & 80 & 83 & 92 & 93 & 89 & 80 & 88 & 42 & 133 & 126 & 105 & 97 & $80-205$ & 127 & $42-224$ & 121 & 124 \\
\hline Magnesium & 34 & 67 & 59 & 71 & 129 & 154 & 123 & 146 & 119 & 135 & 63 & 68 & 56 & 61 & 59 & 56 & 64 & 74 & 48 & 37 & 79 & 128 & 25 & 27 & $25-129$ & 72 & $27-154$ & 85 & 79 \\
\hline Chloride & 253 & 297 & 199 & 204 & 183 & 208 & 174 & 198 & 169 & 190 & 112 & 121 & 100 & 108 & 131 & 129 & 130 & 124 & 184 & 154 & 131 & 152 & 129 & 139 & $100-297$ & 158 & $108-253$ & 169 & 164 \\
\hline Sulphates & 360 & 460 & 325 & 225 & 480 & 505 & 458 & 480 & 544 & 469 & 500 & 550 & 445 & 490 & 500 & 495 & 450 & 500 & 325 & 310 & 445 & 461 & 340 & 350 & $325-544$ & 432 & $225-550$ & 440 & 436 \\
\hline Nitrate & 0.3 & 0.3 & 0.3 & 0.4 & 0.2 & 0.4 & 0.4 & 0.3 & 0.1 & 0.2 & 0.1 & 0.3 & 0.4 & 0.5 & 0.1 & 0.2 & 0.5 & 0.5 & 0.5 & 0.6 & 0.5 & 0.6 & 0.4 & 0.6 & $0.1-0.5$ & 0.32 & $0.2-0.6$ & 0.4 & 0.36 \\
\hline $\begin{array}{l}\text { Total } \\
\text { Phosphate }\end{array}$ & 0 & 0.03 & 0.04 & 0.04 & 0.03 & 0.04 & 0.03 & 0.04 & 0.04 & 0.05 & 0.03 & 0.04 & 0.03 & 0.06 & 0.03 & 0.04 & 0.04 & 0.05 & 0.04 & 0.1 & 0 & 0 & 0.03 & 0.04 & $0.02-0.04$ & 0.03 & $0.03-0.05$ & 0.05 & 0.04 \\
\hline $\begin{array}{l}\mathrm{Fe} \\
\mathrm{Pb} \\
\mathrm{Cu} \\
\mathrm{Zn}\end{array}$ & $\begin{array}{l}0 \\
\text { Nill } \\
- \\
-\end{array}$ & 0.05 & 0.03 & 0.04 & 0.03 & 0.05 & 0.02 & 0.03 & 0.04 & 0.04 & 0.04 & 0.05 & 0.04 & 0.03 & 0.02 & 0.03 & 0.03 & 0.03 & 0.04 & 0 & 0 & 0 & 0.02 & 0.03 & $0.02-0.04$ & 0.03 & $0.03-0.05$ & 0.03 & 0.03 \\
\hline
\end{tabular}

(Saad and Antoine, 1978; Al-Saadi and Mayah, 1983; Abbawi and Hassan, 1990; Maulood, 1993a, 1994, Hassan, 1997; Al-Lami et al, 1988, 1999; Rasheed et al., 2001; Al-Mashkoor, 2006).

The highest values of dissolved oxygen were recorded during January and on the other hand, the values decreased towards the month of August (Table 2). The effect of city pollutants was evident on the values of values South of the city (site 3). The values decreased from 12.1 to $9.1 \mathrm{mg} \mathrm{L}^{-1}$ North of the city (location 2), including 11.2 to $8.2 \mathrm{mg} \mathrm{L}^{-1}$ South of the city (location 3 ), respectively (Table 2). The effect of temperature increases during the summer months and household waste in sewage water is evident in the rates of dissolved oxygen values. The oxygen produced by large photosynthesis during the summer is due to high temperatures (Welsh, 1996) this is in addition to the role of household wastes rich in organic matter in stimulating the growth and reproduction of microorganisms in the sewage and thus in the river and in the consumption of oxygen required for oxidation (Al-Issa, 1981; Al-Saadi et al, 1986; Al-nashea, 2002) and the accompanying increase in the concentration of $\mathrm{CO}_{2}$ gas in addition to the negative impact of water volume and increase evaporation and slow flow in the river during the summer months on the amount of dissolved oxygen through increased density of vegetation and the phenomenon of food enrichment and the emergence of unacceptable smells in the river water, this is confirmed by a number of researchers (Muhhamed, 1986, Sabri, 1989; Al-Rubaie, 1997; Al-Lami et al, 1988, 2001). The values of dissolved oxygen and its rates at all sites and months of the year are more than the values of the Iraqi parameters of the 1967 River Pollution Conservation System (Abbawi and Hassan, 1990), the Iraqi Environmental Legislations of 1988 (more than $5 \mathrm{mg} \mathrm{L}^{-1}$ ) for drinking water and the values of the (WHO., 1980) that divided the water into three types depending on the concentration of oxygen an excellent source, good and bad if the values between (6.5-7.5) and (4.0-6.5) and $<4 \mathrm{mg} \mathrm{L}^{-1}$, respectively. The first needs to be sterilized, the second is sterilization and traditional treatment and the third is sterilization, traditional treatment and assistance but comes close to the upper limit of the Tigris from upstream to downstream (Al-Mashkoor, 2006) (with a general range between (9.5-2.5) and a general average of $7.1 \mathrm{mg} \mathrm{L}^{-1}$ ), the total values were between the limits of the Tigris between Mosul and Kut (Al-Lami et al., 1999) between (6.6 and 13.6) and the rate of $\left(9.7 \mathrm{mg} \mathrm{L}^{-1}\right)$. This is due to the nature of good ventilation of water bodies in Iraq (Sabri et al, 1989, Maulood et al., 1994, Al-Lami and Al-Obeidi, 1996, Al-Rubai, 1997, Hassan, 1997, Al-Lami et al, 1998, 2001; Rasheed et al., 2001). Table 1 and 2 show the high values of total soluble solids (salinity), turbidity and electrical conductivity in some months of the study year in the second location (North of the city) compared to other sites, especially, the third (South of the city),under the influence of city pollutants (756 $\mathrm{mg} \mathrm{L}^{-1}, 27 \mathrm{NTU}$ and $1123 \mu \mathrm{mhos} \mathrm{cm}^{-1}$ ) were recorded at the second site and decreased to $735 \mathrm{mg} \mathrm{L}^{-1}, 26 \mathrm{NTU}$ and $1218 \mu \mathrm{mhos} \mathrm{cm}^{-1}$ at the third site, respectively. This is due to several reasons including agricultural practices North of the city in addition to the fact that the river flow section and several kilometers North of the second site is in the direction of the winds of the North-West and South-Eastern winds in some months of the year (Fig. 1) which affect the velocity of water currents and the movement of waves that cause the erosion of the bottom mud and the edges of the river and reduce their deposition and thus increase the values of these variables, especially, soluble solids which match what Saleh et al. (1980) on the impact of agricultural practices and the turbidity of river water that match what White and his group (White and Hartland-Rowe, 1969). That the abundance of river water flow in some months have a clear effect in reducing the 


\section{J. Eng. Applied Sci., 14 (Special Issue 9): 10642-10649, 2019}

concentration of the values of these variables resulting from the remnants of the city of Al-Diwaniyah and that the rainfall in some months of the year influence the increase in the values of these variables because of the erosion of the edges of the river and most sites and the movement of muddy and organic matter at the bottom of the river during the study period, the presence of a number of buffalo breeders in the area between the first and second and the values of electrical conductivity values of total soluble solids are increasing southward to the properties of soil and household waste along and the two sides of the riverbed (Weinert, 1989) and there was no noticeable effect for the Rubber and textile factories on the values of these variables during the month of November 2013 and 2014 (Table 1) and may be due to the interruption of production or less and the associated non-pumping quantities of pollutants in the river water. When comparing the values of the general average of the above environmental variables (Table 2) with the values of some international and Iraqi specifications and some local studies on the Al-Diwaniyah, Euphrates and Tigris Rivers it is clear that the general average values of soluble solids in Al-Diwaniyah River (853 $\mathrm{mg} \mathrm{L}^{-1}$ ) is higher than that of the US Public Health Service (1962) and the US Environmental Protection Agency (Abbawi and Hassan,1990) which recommended (500 $\mathrm{mg} \mathrm{L}^{-1}$ ) in drinking water but close to what Abdul Redha et al. (1996) found in Al-Diwaniyah river before the city (792 $\mathrm{mg} \mathrm{L}^{-1}$ ) and more than in Al-Diwaniyah river before the city (555 $\mathrm{mg} \mathrm{L}^{-1}$ ) but falls within the values of each of the Euphrates River before and after the city of Al-Samawah (Al-Mashkoor, 2002) (600 and $1000 \mathrm{mgL}^{-1}$ ) and the overall extent of the Tigris river from upstream downstream (Al-Mashkoor, 2006) (266-2133 $\mathrm{mg} \mathrm{L}^{-1}$ ) and an average of $\left(1010 \mathrm{mg} \mathrm{L}^{-1}\right)$ and less than in the middle of the Euphrates River in the city of Al-Kufa (1420 $\mathrm{mg} \mathrm{L}^{-1}$ ).

Classification of river water sources which require traditional treatment+sterilization (Abu Giedria, 1988) NTU (10-250) and comes close to the upper limit of WHO values (WHO., 1980) (5-25) (NTU) but more than the US Environmental Protection Agency (cited from Abbawi and Hassan, 1990), the World Health Organization (1984), the European Union (EC, WEDC, 1987) and the Iraqi specifications (Abbawi and Muhammad,1990) for drinking water (1, 5, 1-10 and >10) NTU. The value is close to that of AbdulRedha et al., (1996) in the waters of the Al-Diwaniyah river before the city (NTU 27) and less than what Sarhan et al. found for the same river before the city (NTU 89) and Al-Mashkoor (2002) of the Euphrates River before and after the city of Al-Samawah (NTU, 170, 300). The value comes close to the upper limit of the Tigris river (Al-Mashkoor, 2006) (2.5-26) and the overall rate of NTU is 8.4.
The average water conductivity $\left(1203 \mu\right.$ mhos $\left.^{-1}\right)$ is greater than that of the European Union (32) in drinking

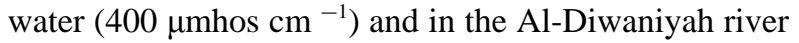
before the city (Abdul Redha et al., 1996) (810 and 920) $\mu$ mhoscm $^{-1}$, respectively and more than in the Euphrates river before and after the city of Al-Samawah (Al-Mashkoor, 2002) (476 and 598) $\mu$ mhos $\mathrm{cm}^{-1}$ and the Tigris river from the upstream downstream (Al-Mashkoor, 2006) between (130-800) and the general rate of $293 \mu$ mhos $\mathrm{cm}^{-1}$. Al-Diwaniyah contaminants increased the values of total alkaline, total hardness, magnesium, chlorides, sulfates, nitrates and total phosphates except calcium. This was evident in the third location (South of the city) compared to the second site (North of the city) and most of the study months (Table 1 and 2). This effect was more pronounced on the rates of the values of these variables in these sites, both individually and in contrast to the above variables which resembled the behavior of calcium in that due to the large concentration of insoluble calcium carbonate in the installation of shell casings and many of the aquatic animals that are fertilized in the water of the river as a result of swimming buffalo animals in the North of the city and caused by the mud-bottom erosion of these deposits. When comparing the values of the general averages of the above variables with some international and Iraqi specifications and some local studies, it is clear that the general average of the total base values (114 $\mathrm{mg} \mathrm{L}^{-1}$ ) (Table 2) is below the limits of the draft Iraqi Standard (Abbawi and Hassan, 1990) for drinking water between (170-200 $\mathrm{mgL}^{-1}$ and less than what Abdul Redha et al. (1996) found in the waters of Al-Diwaniyah river before the city (388 $\mathrm{mg} \mathrm{L}^{-1}$ ) but within the range found by AL-Lami et al. (1999) in the Tigris river between (112-224) and the rate of $138 \mathrm{mg} \mathrm{L}^{-1}$. The overall average values of total precipitation values (569 $\mathrm{mg} \mathrm{L}^{-1}$ ) (Table 2) are close to the highest values of Iraqi standards (IRPR,1981) and WHO (1980) for drinking water (500 $\left.\mathrm{mg} \mathrm{L}^{-1}\right)$ but more than those found by Sarhan et al. (2000) and Abdul Redha et al. (1996) in the same river before the city (202 and 204 $\mathrm{mgL}^{-1}$ ), respectively and Al-Mashkoor (2002) in the Euphrates before and after the city of Al-Samawah (160-190 $\mathrm{mg} \mathrm{L}^{-1}$, respectively. The value came within the limits of the general range of the Tigris river from the source upstream (Al-Mashkoor, 2006) between (440-960) and the rate of $604 \mathrm{mg} \mathrm{L}^{-1}$. The general average calcium values in the river water (124 $\mathrm{mg} \mathrm{L}^{-1}$ ) (Table 2) and within the limits of the World Health Organization (1995) (75-200 $\mathrm{mgL}^{-1}$ ) for potable water and the g eneral size of the Tigris river (Al-Mashkoor, 2006) -72) 160) and a general average of $117 \mathrm{mg} / \mathrm{L}$ and more than the specifications of the European unit (EC, WEDC, 1987) and Iraqi specifications (IRPR, 1981) (100 and $7 \mathrm{mg} \mathrm{L}^{-1}$ ), 


\section{J. Eng. Applied Sci., 14 (Special Issue 9): 10642-10649, 2019}

respectively in drinking water and less than the general range of American public water (200-3000 $\mathrm{mg} \mathrm{L}^{-1}$ ) and more than found by both in the same river before the city (30 $\mathrm{mg} \mathrm{L}^{-1}$ ) and the value was less than what Abdul Redha et al. (1996) in the waters of the AlDiwaniyah river before the city $\left(156 \mathrm{mg} \mathrm{L}^{-1}\right)$. The general average values of magnesium (79 $\mathrm{mg} \mathrm{L}^{-1}$ ) were within the limits of the World Health Organization (1980) (30-150 $\mathrm{mg} \mathrm{L}^{-1}$ and more than the upper limit of the specifications of the European unit (EC, WEDC, 1987) and Iraqi specifications (IRPR, 1981) (50 mg L ${ }^{-1}$ ) for drinking water within the general range of US public water (50-1500) and an ideal rate of $250 \mathrm{mg} \mathrm{L}^{-1}$ within the overall range of the Tigris River (Al-Mashkoor, 2006) (45-134) and a rate of $73 \mathrm{mg} \mathrm{L}^{-1}$ and more than in the Al-Diwaniyah river before the city (Abdul Redha et al., 1996) (10 and $32 \mathrm{mg} \mathrm{L}^{-1}$ ), respectively.

The total values of chloride values (164 $\mathrm{mg} \mathrm{L}^{-1}$ ) (Table 2) were lower than those of the World Health Organization (1980), Iraqi standards (Abbawi and Muhammad,1990) (200-600 $\mathrm{mg} \mathrm{L}^{-1}$ ), US Public Health Administration (1962), The United States Environmental Protection Agency (Abbawi and Muhammad,1990), the World Health Organization (1984) (250 $\mathrm{mg} \mathrm{L}^{-1}$ ) in drinking water, the 1967 Iraqi Standards for River Water (Abbawi and Muhammad,1990) and 1981 for drinking water (IRPR, 1981) (200 $\mathrm{mg} \mathrm{L}^{-1}$ ) in the American public water (100-3000) and an ideal rate of $500 \mathrm{mg} \mathrm{L}^{-1}$, and within the amount found by Al-Mashkoor (2006) in the Tigris river (99-918 $\mathrm{mg} \mathrm{L}^{-1}$ ) and a rate of $340 \mathrm{mg} \mathrm{L}^{-1}$ and AL-Lami et al. (1999) in the Tigris river (43.5-383 mg $\mathrm{L}^{-1}$ ). The values were more than the specifications of the European unit (EC, WEDC, 1987) (25 mg L ${ }^{-1}$ ) and what was found by Abdul Redha et al. (1996) and Sarhan et al. (2000) in the waters of Al-Diwaniyah before the city (120-142 $\mathrm{mg} \mathrm{L}^{-1}$ ), respectively.

The general average of sulfur values recorded a high concentration (436 $\mathrm{mg} \mathrm{L}^{-1}$ ) in river water (Table 2), this is due to the impact of domestic and industrial waste in some cities of Babil province such as detergents, acidic acid, tires, textiles, dates as well as household and industrial wastes for Rubber and Textile. Al-Saadi et al. (1986) mentioned that the source of sulphates in the Iraqi rivers is a number of industries whose waste leaks into rivers such as fertilizer, paper, oil refining, etc. In normal cases of river water, the amount of sulphates does not exceed (12 $\mathrm{mg} \mathrm{L}^{-1}$ ) (Abbawi and Hassan, 1990) (200-400 $\mathrm{mg} \mathrm{L}^{-1}$ ), US Environmental Protection Agency (Abbawi and Muhammad,1990) (250 $\mathrm{mg} \mathrm{L}^{-1}$ ) for drinking water and more than Iraqi specifications (Abbawi and Muhammad, 1990) of river water (200 $\mathrm{mg} \mathrm{L}^{-1}$ or more) and more than the European Union (EC, WEDC, 1987) for drinking water limit (25-250 $\left.\mathrm{mg} \mathrm{L}^{-1}\right)$ but less than what found in the Al-Diwaniyah river after textile and rubber plants (500 $\mathrm{mg}$ ) and more than the value found by
Abdul Redha et al. (1996) and (360 and 264 mg L ${ }^{-1}$ ), respectively in the waters of Al- Diwaniyah river before the city and Al-Mashkoor (2006) between (3-18) and an average of $\left(9.6 \mathrm{mg} \mathrm{L}^{-1}\right)$ in the Tigris river from the upstream to downstream but the above value falls within the overall range of US public Water (Peavy et al., 1987) (100-1500) and an ideal rate of (300 $\left.\mathrm{mg} \mathrm{L}^{-1}\right)$. The average nitrate $0.36 \mathrm{mg} \mathrm{L}^{-1}$ (Table 2) is lower than that of WHO (1980), the US Public Health Administration (1962) (45 $\mathrm{mg} \mathrm{L}^{-1}$ ), the World Health Organization (1984), the US Environmental Protection Agency (Abbawi and Hassan, 1990) and drinking water (Abbawi and Hassan, 1990) (15 and $20 \mathrm{mg} \mathrm{L}^{-1}$ ), respectively and in the waters of the Euphrates river in the city of Al-Kufa $\left(9 \mathrm{mg} \mathrm{L}^{-1}\right)$ and as found by Al-Mashkoor (2002) in the water of the Euphrates before and after the city of (Al-Mashkoor, 2002) (2006 $\mathrm{mg} \mathrm{L}^{-1}$ ), respectively and less than the general range mentioned by Peavy et al. in the American public waters (5-40) and an average of (25 $\left.\mathrm{mg} \mathrm{L}^{-1}\right)$ less than the general range and the general average of the Tigris river (Al-Mashkoor, 2006) (1.4-5.6) and ( $3 \mathrm{mgL}^{-1}$ ), respectively. The value was within the limits found by AL-Lami et al. (1999) in Tigris river water (0.177-1.676 $\mathrm{mg} \mathrm{L}^{-1}$ ).

The overall average values of total phosphate (organophosphate), organic phosphate and polyphosphate in the waters of the Al-Diwaniyah river were (0.04 $\mathrm{mg} \mathrm{L}^{-1}$ ) (Table 2). This value was lower than the values of many specifications and studies including the determinants of the maintenance of rivers and Iraqi public water from pollution in 1967 (Abbawi and Hassan, 1990) ( 0.4 and $3 \mathrm{mg} \mathrm{L}^{-1}$ ) in river water and in the discharged water, respectively and the limits mentioned by Peavy et al. (1987) in the American public water between (1-50) and the ideal value of $20 \mathrm{mg} \mathrm{L}^{-1}$ and less than that Al-Mashkoor (2002) found in the water of the Euphrates river before and after the city of Al-Samawah (1.4 and $11.9 \mathrm{mg} \mathrm{L}^{-1}$ ) but the value was more than that in the draft Iraqi Standard for drinking water (Abbawi and Hassan, 1990) which recommended the value of organic phosphorus $\left(0.0 \mathrm{mg} \mathrm{L}^{-1}\right)$.

That the presence of phosphorus in the water coupled with the presence of high concentration of nitrogen causes the phenomenon of food enrichment which promotes the growth of aquatic plants and consumption of dissolved oxygen and thus the deterioration of water quality and the elimination of aquatic life (Saleh et al., 1980). On the contrary, it was observed in the water of the Al-Diwaniyah river where the low values of both nitrates and phosphates may be due to the abundance of its flowing water, especially in 2014 which caused a reduction in the concentration of the values of these two high variables in the sewage directly dumped the river and loaded with human waste rich in nitrogen sources and powders phosphate-rich washing as well as the effect of 
food and agricultural waste on the concentration of these two variables. This phenomenon is confirmed by many researchers including Hammer (1985).

\section{CONCLUSION}

The overall average trace mineral values in river water were rare (Nill) for lead, copper and zinc and the value of $0.03 \mathrm{mg} \mathrm{L}^{-1}$ for iron was less than WHO. (1980) (0.1-1.0 $\mathrm{mg} \mathrm{L}^{-1}$ ) and the value of Iraqi specifications for river water and waste water (Abbawi and Muhammad, 1990) (0.3 and $2 \mathrm{mg} \mathrm{L}^{-1}$ ), respectively and Iraqi Standard for drinking water for 1986 (Abbawi and Muhammad, 1990) (0.5 $\mathrm{mg} \mathrm{L}^{-1}$ ), the World Health Organization (1980) and the US Environmental Protection Agency 1971a (0.3 $\left.\mathrm{mg} \mathrm{L}^{-1}\right)$.

\section{REFERENCES}

AL-Lami, A.A., T.I. Kassim and A.A. AL-Dylymei, 1999. A limnological study on Tigris River, Iraq. Sci. J. Iraqi Atomic Energy Commission, 1: 83-98.

AL-Nimma, B.A.B., 1982. A study on the limnology of the Tigris and Euphrates Rivers. M.Sc. Thesis, Salahaddin University-Erbil, ?Erbil?, ? Iraqi Kurdistan.

APHA, AWWA, WPCF, 1985. Standard Methods for the Examination of Water and Waste Water. 16th Edn., Port City Press, Baltimore Maryland, Pages: 1268.

Abawi, S.M. and M.S. Hassan, 1990. Practical Engineering of the Environment-Water Testing. University of Mosul, Mosul, Iraq,.

Abdul Redha, N.A, A.H. Hassan, H. Falah and J.M. Faris, 1996. Evaluation of drinking water specifications in Diwaniyah. J. Al Qadisiyah, 3: 53-61.

Abed Ali, M.N., A.R. Ali, K.H. Sami and G.T. Ahmad, 2000. The Biological impact of industrial wastes of fabric and rubber processors on the Diwaniyah River: Specification. J. Al Qadisiyah, 5: 28-40.

Abu Giedria, Y.B., 1988. The development and distribution of plankton in white nillc. Hydrobiologia, 38: 85-94.

Al-Issa, S.A.A., 1981. A study of the ideology on the shatt al-Arab and the Trench river. Master Thesis, University of Al-Basrah, ?Basrah, Iraq.

Al-Lami, A.A., A.W. Sabri, K.A. Muhsen and A.A. Al-Dulymi, 2001. [Ecological effects of Tharthar arm on Tigris river: A-physical and chemical parameters (In Arabic)]. Sci. J. Iraqi Atomic Energy Commission, 3: 122-136.

Al-Lami, A.A., H.A. Al-Saadi, T.I. Kassim and K.H. Al-Aubaidi, 1988. On the limnological features of Euphrates river, Iraq. J. Educ. Sci., 29: 38-50.
Al-Lami, A.A.Z. and K.H. Al-Obeidi, 1996. Study of some physical and chemical characteristics of the Tharthar Reservoir-Iraq. J. Coll. Educ. Girls Univ. Baghdad, 2: 20-28.

Al-Mashkoor, S.K.H., 2002. The effects of sewage and industrial waste on the Euphrates in Al-Samawah city. J. Al Qadisiyah, 7: 29-41.

Al-Mashkoor, S.K.H., 2006. Determination of physical and chemical properties of potable water in the city of Kut. J. Babylon Univ., 12: 929-940.

Al-Rubaie, M.A.H.J., 1997. Environmental study on the Great River and its impact on the Tigris River. Master Thesis, University of Baghdad, Baghdad, Iraq.

Al-Saadi, H.A. and A.R.A. Mayah, 1983. Aquatic Plants in Iraq. Publications of the Center for Arabian Gulf studies in University Basrah, ?Basrah, Iraq,.

Al-Saadi, H.A., N.B. Al-Reham and L.A.J. Al-Hassan, 1986. Aquatic ecology, ministry of higher education and scientific research. University of Basrah,? Basrah, Iraq.

Alnashea, A.A.R., 2002. Food enrichment in the Daghara river and its implications for the use of water in the city of Afak. J. Al Qadisiyah, 7: 52-63.

Anonymous, 1960. Approved methods for the physicals and chemical examination of water. Department of Health London, London, England, UK.

Blum, J.L., 1976. An ecological study for the olgae of the Saline river Michigan. Hydrobiologia, 11: 214-225.

Buhrmann, F., M. van der Waldt, D. Hanekom and F. Finlayson, 1999. Treatment of industrial wastewater for reuse. Desalination, 124: 263-269.

Dart, R.K. and R.J. Stretton, 1980. Microbiological Aspects of Pollution Control. Elsevier Scientific Publisher, Amsterdam, pp: 265.

EC, WEDC., 1987. Developing World Water. Grosvenor Press International, UK.,.

EPA., 1971. Office of water programs temperature. U.S. Environment Protection Agency, Washington, D.C., USA.

Eisen, A.K. and J.M. Anderson, 1988. Ecology for Environmental Science. Edward Arnold, London, UK.,.

Hammer, U.T., 1985. Treatise on Limnology. John Willey and Sons, ?Hoboken, New Jersey, USA..

Hassan, F.M., 1997. A liminological study on Hilla River. Al Mustansiriyah J. Sci., 8: 22-30.

Hynes, H.B., 1972. The Ecology of Running Wastes. Liverpool University Press, Liverpool, UK.,.

Lind, O.I., 1979. Handbook of Common Methods in a Limnology. C.V. Mosby Company, Maryland Heights, Missouri,. 
Maulood, B.K., H.A. Al-Saadi and R.A.M. Hadi, 1993. A liminological study of Tigris, Euphrates and shatt Al-Arab, Iraq, Mu’tah. J. Res. Stud., 8: 53-67.

Maulood, B.K., M.N. Al-Azzawi and H.A. Saadalla, 1994. An ecological study on the Tigris river pre and after crossing Baghdad. J. Coll. Educ. Women, 5: 43-50.

Mohammed, S.A., 1986. Pollution of water sources in Iraq by residential and industrial waste. Master Thesis, University of Mosul, Mosul, Iraq.

Rasheed, K.A., A.W. Sabri, A.A. Al-Lami, T.I. Kassim and S.F. Shawkat, 2001. Distribution of some heavy metals in water, suspended solids, sediments, fish and aquatic plants of the river Tigris, Iraq. Sci. J. Iraqi At. Energy Commission, 3: 198-208.

Saad, M.A. and S.E. Antoine, 1978. Limnological studies on the river Tigris, Iraq III. Phytoplankton. Int. Rev. Gesamten Hydrobiol. Hydrographie, 63: 801-814.

Sabri, A.W., B.K. Maulood and N.E. Suliaman, 1989. Limnological studies on river Tigris: Some physical and chemical characters. J. Biol. Sci. Res. Baghdad JBSREF., 20: 565-579.

Saleh, T.M., N.S. Caesar and S. Abdul Hadi, 1980. Introduction to Environmental Sciences and Technology. University of Mosul, Mosul, Iraq,
The American Water Works Association, Inc., 1971. Water quality and treatment. 3rd Edn., McGraw-Hill Book Company, New York, USA, pp: 1-49.

US Public Health Service, P.H.S., 1962. Public health service drinking water standards. US Public Health Service Publication No. 956, US Government Printing Office, Washington DC.

WHO, 1994. Guidelines for Drinking Water Quality Recommendation. 2nd Edn., World Health Organization, Geneva.

WHO., 1980. International Standards for Drinking Water. 3rd Edn., World Health Organization, Geneva, Switzerlan,.

Walker, G.M. and L.R. Weatherley, 1999. Biological activated carbon treatment of industrial wastewater in stirred tank reactors. Chem. Eng. J., 75: 201-206.

Weinert, E., 1980. The vegetation zones of Iraq bielefelder Okolog. Beitr, 4: 45-57.

Welsh, P.S., 1996. Limnology. 18th Edn., Mc Graw-Hill, New York, USA.,.

White, G.E. and R. Hartland-Rowe, 1969. Temporal changes of physical and chemical factors in a shallow astatic saline lake. Int. Ver. Theor. Angew. Limnol. Ver., 17: 440-446. 